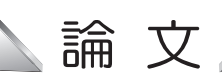

Original Paper

\section{幌延地域に分布する珪質岩に対する幾つかの 岩盤応力測定法の適用性と推定された応力状態 *}

\title{
Applicability of Initial Stress Measurement Methods to Horonobe Siliceous Rocks and Initial Stress State around Horonobe Underground Research Laboratory
}

\author{
Hiroyuki SANADA ${ }^{\mathrm{a}}$, Sumio NIUNOYA ${ }^{\mathrm{b}}$, Hiroya MATSUI ${ }^{\mathrm{c}}$ and Yoshiaki FUJII ${ }^{\mathrm{d}}$
}
a. Sedimentary Environment Engineering Group, Horonobe Underground Research Unit, Geological Isolation Research and Development Directorate, Japan Atomic Energy Agency (Corresponding author E-mail: sanada.hiroyuki@jaea.go.jp / FAX: 01632-5-2344)
b. Obayashi Corporation
c. Crystalline Environment Engineering Group, Tono Geoscientific Unit, Geological Isolation Research and Development Directorate, Japan Atomic Energy Agency
d. Division of Solid Waste, Resources and Geoenvironmental Engineering, Graduate School of Engineering, Hokkaido University

\begin{abstract}
Understanding initial stress condition in deep underground is important for such construction as rock cavern for geological disposal of HLW and underground power plant. Neogene sedimentary rock is widely distributed in Japan. There are only a few studies of initial stress measurement in Neogene sedimentary rock mass in Japan due to difficulty of measurement. Evaluation of initial stress condition around Horonobe Underground Research Laboratory Project was carried out in order to understand initial stress condition and applicability of AE, DSCA and hydraulic fracturing (HF) methods to Neogene sedimentary rock. Initial stress values obtained from AE method is smaller than overburden pressure due to time dependency of Kaizer effect. It would be difficult to use AE method as initial stress measurement method for Horonobe Siliceous rocks. Principal stress values by DSCA are similar to those by HF tests. Directions of maximum horizontal principal stresses are approximately in E-W and corresponded to HF results.

In HF, rod type and wire-line type systems were compared. Workability of rod type was much better than wireline type. However, re-opening pressure were not able to be precisely measured in case of rod type system due to the large compliance of the packers and rods. Horizontal maximum and minimum principal stresses increase linearly in HF results. Deviatoric stress is acting at shallow depth. Initial stress condition approaches hydrostatic condition with depth. Direction of maximum horizontal principal stress was in E-W direction which was similar to tectonic movement around Horonobe URL by triangular surveying.
\end{abstract}

KEY WORDS: Geological Disposal, Hydraulic Fracturing, AE, DSCA, Horonobe Underground Research Laboratory Project

\section{1. 緒 言 \\ わが国には，新第三紀や第四紀などの年代の若い堆積岩が広く 分布しており，これらが地下構造物（高レベル放射性廃棄物の地}

*2009年 3 月 13 日受付 2009 年 9 月 16 日受理

1. 普通会員 (独) 日本原子力研究開発機構 地層処分研究開発部門 幌 延深地層研究ユニット 堆皘岩工学技術開発グループ

2. (株) 大林組 技術本部 原子力本部 原子力環境技術部 第三課 ( 研 究当時, (独) 日本原子力研究開発機構地層処分研究開発部門 幌延 深地層研究ユニット 堆積岩工学技術開発グループ)

3. (独) 日本原子力研究開発機構 地層処分研究開発部門 東濃地科学研 究ユニット 結晶啠岩工学技術開発グループ サブグループリーダー

4. 普通会員 北海道大学大学院 工学研究科 環境循環システム専攻 教授 [ 著者連絡先 ] FAX: 01632-5-2344

E-mail: sanada.hiroyuki@jaea.go.jp

キーワード: 地層処分, 水圧破砕法, AE 法, DSCA 法, 幌延深地層研究計画
層処分場など）の母岩となるケースが多い。地下深部は，地表か らの土被りや造構作用による初期地圧と呼ばれる応力場の下にあ る。初期地圧は, 構造物の短期・長期的な力学的安定性と密接な 関係があり，支保形態ならびに空洞の形状・寸法を決定する重要 な因子となる。したがって, 構造物の設計段階で対象とする岩盤 内に分布する初期応力状態を把握することが要求される。地下深 部に作用寸る初期応力状態の一般的な傾向は, 斎藤, Brown, Lindner などによって報告されている ${ }^{1-3)}$ が，わが国の地盤は， 地質学的な変動が活発な環境下に晒されているため, 岩盤の堆積 過程において加わった圧密やプレートの運動などによる造構作用 が加わり複雑な応力状態になっている。そのため, 地下深部に作 用する初期地圧の正確な状態を知るには，直接測定する以外に方 法はない。そして, 力学的な性状が比較的安定している硬質な岩 


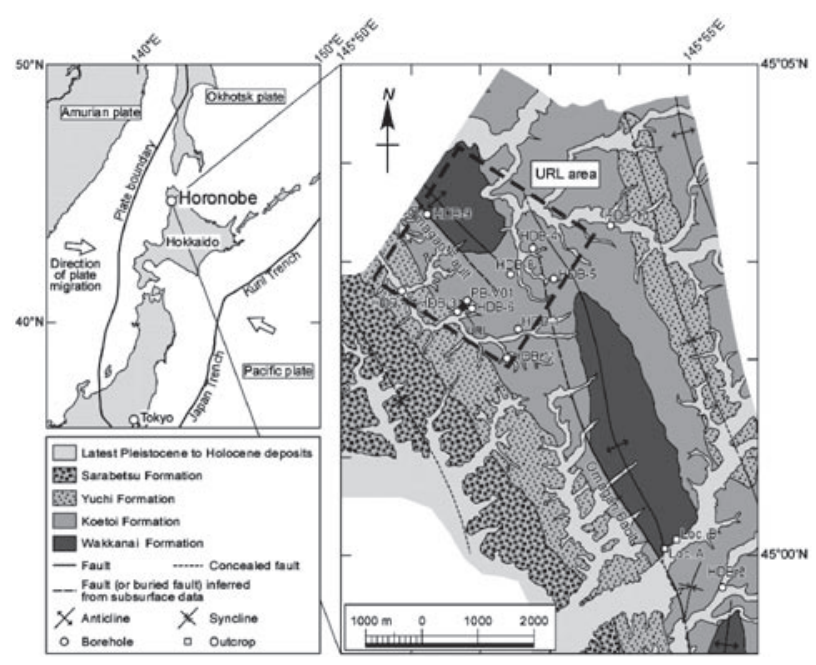

Fig.1 Geological map in the Horonobe area (after Ishii et al., 2006), showing locations of the boreholes. Plate boundaries and directions of plate migration in location map of the left upper are from Wei and Seno (1998).

盤内に施工される地下発電所，地下石油備蓄基地や $L P G$ 地下備 蓄施設などの地下構造物では初期地圧の計測事例が多いが，軟弱 な堆積岩を対象にした場合は，硬質な岩盤と比較して高い計測技 術が要求されることから ${ }^{4)}$, 初期地圧の計測事例はそれほど多 くない5-7)。また, わが国では, 使用済み燃料の再処理過程から 生じる高レベル放射性廃棄物を地下 $300 \mathrm{~m}$ 以深に埋設処分する 「地層処分」が計画されている。現在, 高レベル放射性廃棄物の 地層処分技術に関する研究開発として, 結晶質岩や堆積岩を対象 にし, 地下研究施設の建設を伴う研究プロジェクトを日本原子力 研究開発機構 (以下, 原子力機構) が進めている。処分事業は, わが国の法令上 $300 \mathrm{~m}$ 以深に設けられることになっており，初期 地圧は, 処分場のアクセス坑道・処分パネルに含まれる坑道の周 辺岩盤の安定性や最適な幾何学配置を検討する上で, 重要な要素 の一つとなる。処分事業ならびに処分システムの信頼性向上と実 現可能性を確認する上で, 実際の地質環境に対する処分システム （サイト特性調查を含む）の適用性の確認を進めることが必要と なる。

初期地圧の計測方法は, 主に, 応力解放法や水圧破砕法などの ボーリング孔を利用した原位置での計測と, AE 法, DSCA 法, DRA 法などのボーリング孔から採取したコアを利用した計測 (コ ア法と呼ばれる）とに大別される。応力解放法の実施は, 深部に 位置する調查坑道などからの水平孔を利用した計測がほとんどで あり，地表からの計測は技術的な困難さからほとんどなされてい ない 8)。原位置での計測のうち, 地表から地下深部の応力状態 を把握するための手法としては, 水圧破砕法が最も有望視されて いる。水圧破砕法は, 現在までに国内外の数多くの原位置で計測 が実施されてきた。水圧破砕計測によって取得される重要なデー タの一つであるき裂開口圧は，加圧区間内に注入する流体の圧力 を増加させる過程において, 圧力一時間曲線の挙動が線形挙動か ら非線形挙動に移行する圧力とみなされる。しかしながら, 既往 の研究によって, 測定されるき裂開口圧は水圧破砕の加圧システ ムの剛性と密接な関係があることや，き裂面の凹凸によりき裂の 開口以前に加圧区間内に生じたき裂を通じて流体が浸透するた め, 従来の試験・解析手法の適用性を再考する必要性が生じてき た ${ }^{9)}$ 。また, 硬質な岩盤とは違って, 軟弱な大深度岩盤を対象 に初期地圧を計測する場合, 対象としている岩盤の性状と作用し ている外力に依存するが, 試錐孔周囲に発生する孔壁破壊 (ボア
ホールブレイクアウト) などにより, 孔壁が崩壊し原位置計測が できなくなる恐れがある。そのような場合でも応力状態を把握す るために, 原位置計測以外のオプションを用意しておくことが要 求される。オプションの一つにコア法が考えられるが，コア採取 から試験までの時間と算出される岩盤応力值との関係や応力記憶 の保持時間などが種々の岩石で異なるため, 計測対象とする種々 の岩石に対して同方法の適用性を検討することが必要である。

本研究では, 特に高レベル放射性廃棄物の地層処分に代表され る地下構造物の合理的な設計・施工への寄与を主たる目的とし, 北海道北部に位置する幌延町を一種のケーススタディとして取り 扱い, 幌延地域に分布する新第三紀の珪質岩に対して幾つかの岩 盤応力測定法を適用し, その適用性を検討した。そして, その結 果と深層ボーリング調查で実施した BHTV 結果や計測エリア内 に作用寸る造構作用から北海道幌延地域に作用寸る初期応力状態 について議論した。これらの結果は, 将来実施する処分事業の設 計・施工や信頼性向上に反映可能になることに加え, 処分場周囲 のサイト特性調查を合理的に信頼性を持った形で進める上で有力 な情報になると思われる。以下にその内容について論述する。

\section{2. 研究対象とした地域の地質構造}

研究対象としたサイトは北海道の北部に位置する幌延町であ る。ここでは, 使用済み核燃料の再処理過程で発生する高レベル 放射性廃棄物の地層処分に関する研究開発を原子力機構が進めて いる。この研究開発は幌延深地層研究計画と呼ばれ, 実際の処分 事業で必要となる地質環境の調査・評価技術, 処分場の設計技術 あるいは性能評価技術などを実際の地質環境に対し適用し，それ らの信頼性を向上することを目的としている。

Fig.1 に地下研究施設周辺の地質図を示す 10,11$)$ 。図に示す HDB (Horonobe Deep Borehole) とは, 幌延深地層研究計画の地上 からの調查研究段階で掘削された深層ボーリング孔の名称を意味 している。当該地域は, 中部中新統の増幌層を不整合におおって, 稚内層, 声問層, 勇知層, 更別層がそれぞれ整合漸移関係で累重 している ${ }^{12)}$ 。地下研究施設周辺の岩盤は, 珪藻を起源とした珪 藻質泥岩の声問層が上位層に, 珪質泥岩の稚内層が下位層に分布 している。両層の境界付近には, 珪藻質泥岩から珪質泥岩一と遷 移的に変化する領域 (遷移帯) が存在していることがわかってい る。勇知層は細粒砂岩から構成され層理に之しく軟質な岩相を呈 し, 更別層は碩岩, 砂岩, シルト岩の不規則な互層から構成され $3^{12)}$ 。主な研究対象地層は声問層, 稚内層であり, その工学的 な特徵は, 声問層は一軸圧縮強さ約 $5 \mathrm{MPa}$ 以下, 有効空隙率 $60 \%$ 程度, 稚内層は一軸圧縮強さ約 $20 \mathrm{MPa}$ 以下, 有効空隙率 $30 \%$ 程度を示し, 多孔質かつ軟弱であることがあげられる ${ }^{13)} 。$ また, 泥岩ではあるものの粘土鉱物は少ないことから, 耐スレー キング性指数は高く, 膨潤圧は小さくいわゆる膨潤性地山ではな (13)。そして, 地下水位は地表面に近く原位置岩盤はほぼ含水 飽和状態にある。

また, Fig. 1 に示すように研究所設置地区を二分する形で北北 西一南南東走向の断層 (大曲断層) の存在が推定されている ${ }^{14)}$ 。

\section{AE 法}

$\mathrm{AE}$ 法は, カイザー効果 (ある応力を経験した材料を, 再載荷 した際, 応力が先行值を越えるとAcoustic Emission と呼ばれる弾 性波が生じる現象) を利用し, 室内載荷試験時の $\mathrm{AE}$ 発生数の変 化から初期地圧を算出する方法である。既往の研究により, カイ ザー効果の成立とコア採取からの経過時間との間には密接な関係 があるとされている ${ }^{15)}$ 。そこで, 本試験に先立ち, 幌延地域に 


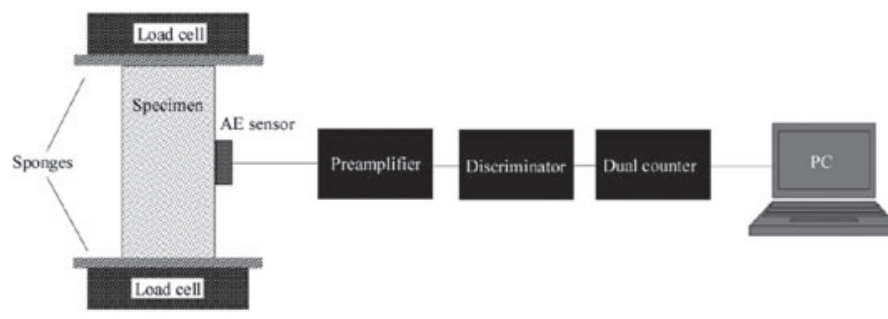

Fig.2 Test equipment of initial stress measurement by AE method.

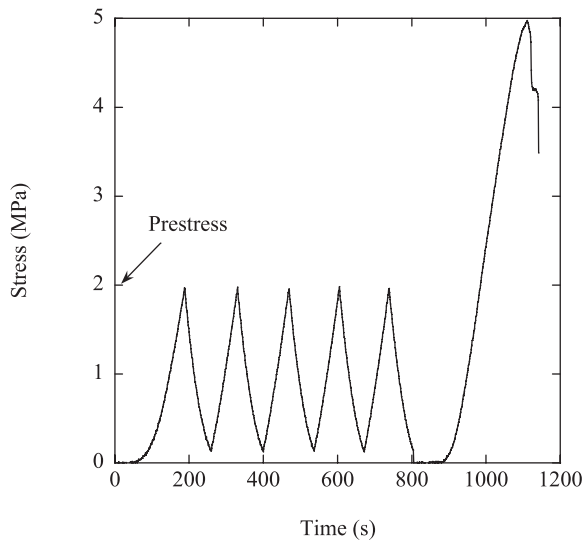

Fig.3 Stress pattern of preliminary test.

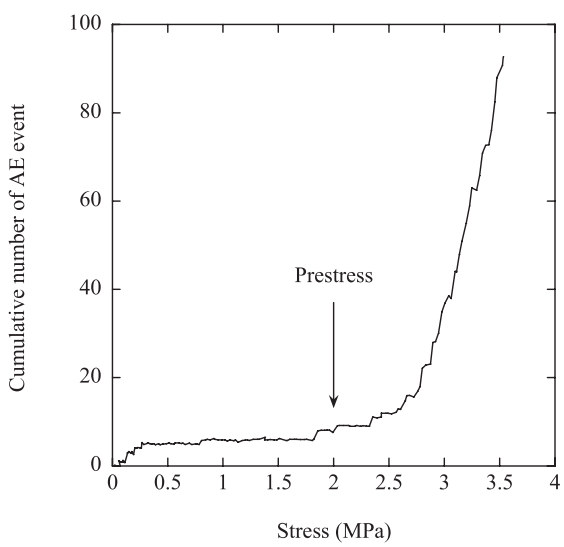

Fig.4 Relationship between cumulative number of $\mathrm{AE}$ event and axial stress in preliminary test.

分布する珪質岩 (声問層, 稚内層の両岩石) に対するカイザー効 果の適用の見通しを確認する目的で，カイザー効果の時間依存性 に関する予備試験を行った。

試験の模式図をFig. 2 に示す。供試体は，直径 $30 \mathrm{~mm}$ ，長さ $60 \mathrm{~mm}$ の円柱形とした。AE センサー (NF， AE-903N，350 kHz 共 振）は含水飽和状態の供試体の側面にシリコングリスを塗布しビ ニールテープにて取り付けた。また，供試体の上下にスポンジを 敷くことで試験機からの振動を $\mathrm{AE}$ として検出しないよう心がけ た。 $\mathrm{AE}$ 信号はプリアンプ (NF, 9913) で $40 \mathrm{~dB}$, ディスクリミネー ター (NF, AE9922, HPF $100 \mathrm{kHz}, \mathrm{LPF} 500 \mathrm{kHz}$ ) で $50 \mathrm{~dB}$ 増幅した。 そして $\mathrm{AE}$ のしきい值を $\mathrm{V}_{\mathrm{L}} 300 \mathrm{mV}, \mathrm{V}_{\mathrm{H}} 350 \mathrm{mV}$ に設定し, 包絡 線検波によるイベント計数法で検出された $\mathrm{AE}$ を, デュアルカウ ンター (NF, AE-932) でカウントし, パーソナルコンピュータで 記録するシステムとした。

予備試験では, Fig. 3 に示すように 5 サイクルの繰返し載荷で 応力履歴を供試体に与え, その後, 軸圧を昇圧させて先行応力之
Table 1 Prestress and delay time.

(UCS means uniaxial compressive strength)

\begin{tabular}{c|c|c}
\hline Case & Prestress & Delay time \\
\hline Case I & UCS $\times 40 \%$ & 8 hours \\
\hline Case II & UCS $\times 40 \%$ & 7 days \\
\hline Case III & UCS $\times 60 \%$ & 1 hour \\
\hline Case IV & UCS $\times 60 \%$ & 8 hours \\
\hline
\end{tabular}

$\mathrm{AE}$ の急増点との関連を調べた。なお，使用したコアは HDB-1 孔 の深度 $300 \mathrm{~m}$ 地点のコア (声問層) である。試験は，材料試験機 のプラテンの変位速度を一定として試験を行った。その結果を Fig. 4 に示す。載荷初期に若干の AE が発生するが, 先行応力以 内ではほぼ変動は見られない。そして, 軸圧が先行応力付近を超 えたあたりから $\mathrm{AE}$ の増加が生じ $\mathrm{AE}$ イベント累積数が急増する ことがわかる。 $\mathrm{AE}$ が急増する応力值と先行載荷により記憶させ た応力值とは概ね一致し，除荷時間をほとんど置かない今回の ケースでは，カイザー効果は成立していると解釈できる。

次に, 先行応力載荷後からの経過時間がカイザー効果の成立に 与える影響を把握するために，一軸圧縮強さの $40 \%$ と $60 \%$ の載 荷圧を約 70 時間加えた後, 任意の時間静置後に再び軸圧を昇圧 させ $\mathrm{AE} の$ 発生数を調べた。予備試験の載荷圧と静置時間を Table 1 に示す。なお，使用した供試体は，HDB-3 孔の深度 $100 \mathrm{~m}$ 付近 (声問層にあたる) のコアである。

結果をFig. 5 に示す。静置時間を比較的長く置いた CaseI, II, IV のケースでは, 先行応力付近でも AE イベント累積数の明瞭 な変化はほとんど見られない。軸圧を昇圧させた場合, その応力 一ひずみの曲線形状は，線形〜非線形〜ひずみ軟化と変化する。 石橋は, 弾性域内で先行応力を除過した場合, カイザー効果に成 立が見られるが, 高い軸圧を載荷し応力ーひずみの曲線形状が軟 化域に近づくにつれ，発生するカイザー効果は徐々に不明瞭にな ることを指摘している 16)。CaseI, II, IV のケースは，載荷圧が一 軸圧縮強さの $40 \%, 60 \%$ と設定した。過去に実施した力学試験 ${ }^{17)}$ によると, 珪質泥岩 (稚内層) の応力ーひず夕曲線は, 降伏圧近 傍でもダイレタンシーのようなものは生じていない。しかし，珪 藻質泥岩 (声問層) は, 降伏点以前でダイレタンシーを生じてい るように見受けられる。今回実施した AE 法の試験は, 材料試験 機のストロークの変位しか計測できていないため, 応力レベルの 増大によるダイレタンシーの発生については, 確かな情報を取得 することが難しいが，既往の調查によると今回設定した応力レ心゙ ルは弾性状態に近いと思われる。そのため, 岩石内部の応力の記 憶機構に影響したカイザー効果が不明瞭になった要因としては, 載荷圧以上に, 先行応力の除荷からの静置時間が長かったことが 挙げられる。一方, Case III のように静置時間が短い場合には, 先行応力後の $3.5 \mathrm{MPa}$ 付近で $\mathrm{AE}$ イベント累積数が微増している。 しかしながら，1 時間程度の経過時間であっても, 先行応力載荷 直後に昇圧させた Fig. 4 と比較して $\mathrm{AE}$ イベント累積数の増加が 不明瞭であり，幌延地域に分布する珪質岩の場合，カイザー効果 に静置時間が与える影響は顕著である。ただし, 上記の考察につ いては, その他の要因 (供試体軸方向の直応力以外の応力成分の 影響, ボーリング時の応力集中の影響, 応力解放による緩みの影 響，原位置岩盤と実験室の温度差による影響等）も今後検討する 必要があると考えている。

コア採取から試験までの時間を極力短くするために，本試験で は全ての試料はコア回収時から 2 日以内で試験を実施することに 


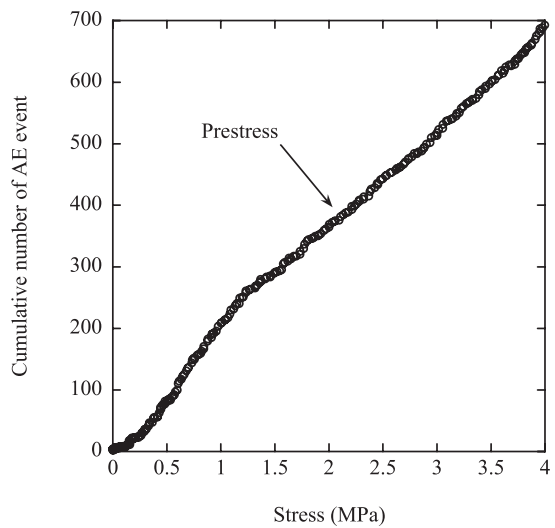

(a) Case I

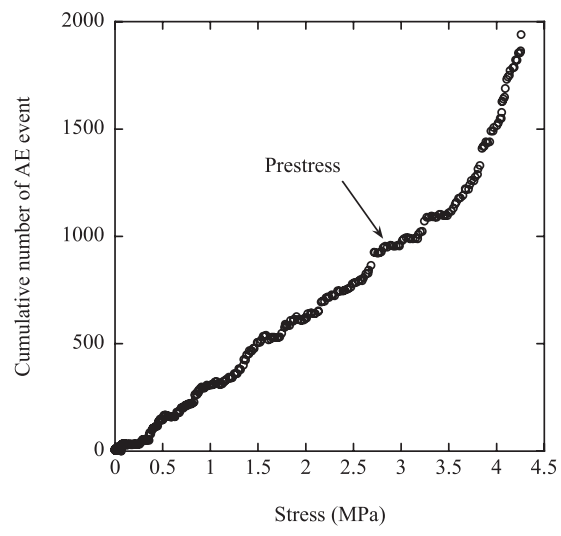

(c) Case III

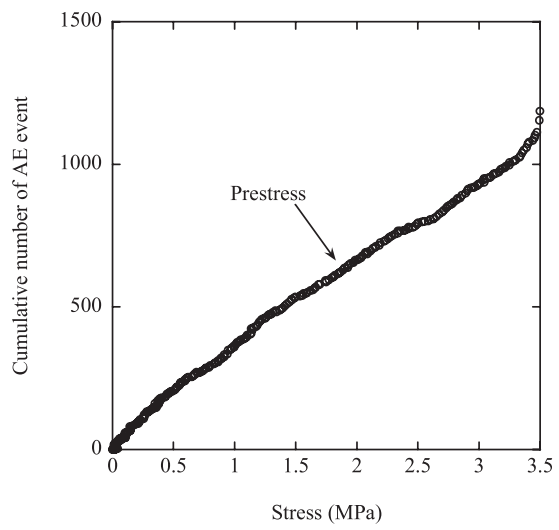

(b) Case II

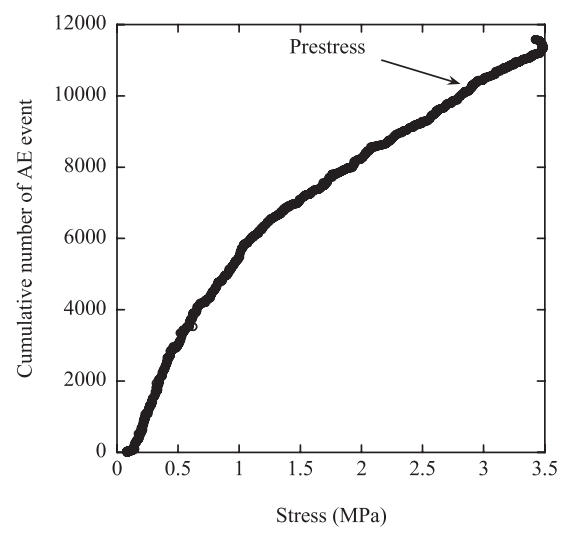

(d) Case IV

Fig.5 Result of preliminary test.

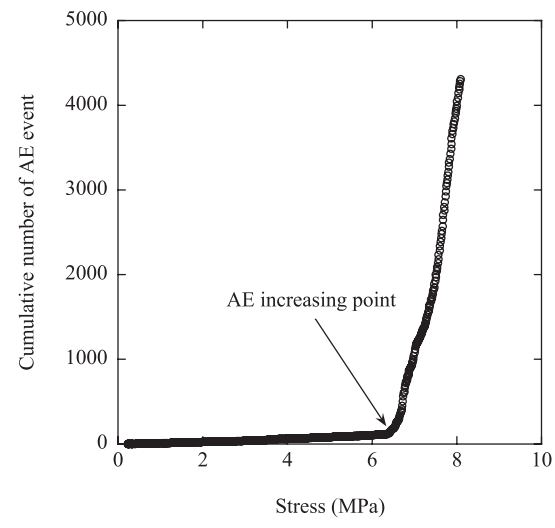

Fig.6 Example of stress-cumulative number of $\mathrm{AE}$ event curve in AE method (HDB-3 GL-439 m).

し，声問層の供試体として HDB-1 孔の $310 \mathrm{~m}$ ，稚内層の供試体 として HDB-1 孔の $468 \mathrm{~m}, \mathrm{HDB}-2$ 孔の $297 \mathrm{~m}, 592 \mathrm{~m}, \mathrm{HDB}-3$ 孔 の $439 \mathrm{~m}$, HDB-5 孔の $381 \mathrm{~m}$ の深度のボーリングコアから直径 $30 \mathrm{~mm}$, 高さ $60 \mathrm{~mm}$ の円柱供試体を作製した。供試体の軸方向は, 鉛直方向と水平方向とし, 水平方向に関しては, 主応力を算定で きるように可能な限り $0^{\circ}, 45^{\circ}, 90^{\circ}, 135^{\circ}$ の方向の供試体を作成 し, 含水飽和状態で試験を実施した。

初期地圧の解析には，AE 急増点が明瞭な試料 (Fig. 6)のみを採 用し $\mathrm{AE}$ 急増点が認められない試料や不明瞭な試料は除外した。

Fig. 7 に本計測で評価された初期地圧と深度の関係について示 す。図には, $\mathrm{AE}$ 測定から算出された鉛直応力, 水平面内最大主

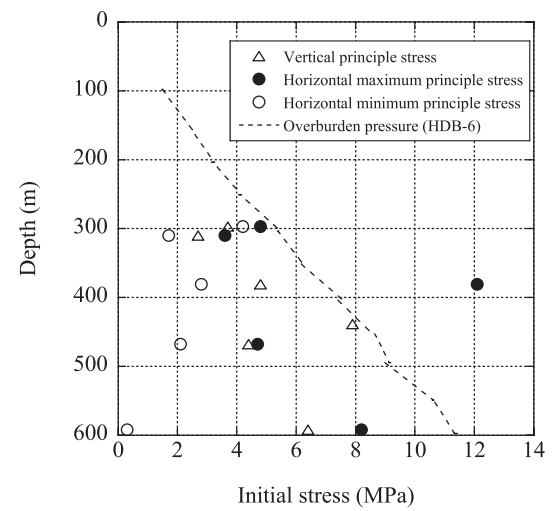

Fig.7 Result of initial stress measurement by AE method.

応力, 水平面内最小主応力, 密度検層から算出した HDB-6 孔の 土被り圧を示す。 $300 \mathrm{~m}$ 近傍での応力值は土被り圧に近く，等方 的な応力状態に近い。そして, 深部に進むにつれて応力值が増加 するが，ばらつきが大きく原位置の応力状態を定量的に示してい るようにはみえない。

\section{DSCA 法}

原位置から採取した岩石試料内では応力解放に伴いき裂が開口 すると考えられる。開口したき裂を含んだ岩石試料に静水圧を作 用させると, き裂閉口に伴うひずみは, 横軸を静水圧, 縦軸をひ ずみとし, 高静水圧下における弾性変形を表す静水圧一ひずみ線 図を静水圧 0 まで外挿したときの $y$ 切片に現れる。このひずみ量 


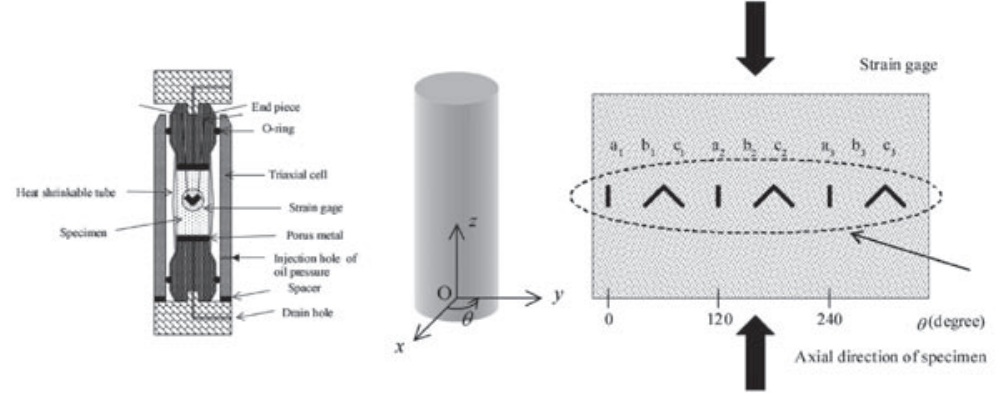

Fig.8 Schematic figure showing triaxial setup and strain gage pattern of DSCA test.

が，直ひずみ方向に原位置で作用していた直応力と比例すると仮 定して地山の主応力比を求める方法が DSCA (Differential Strain Curve Analysis) 法と呼ばれている。本章では, 幌延地域に分布す る珪質岩 (声問層, 稚内層) に対し実施した DSCA 試験について 述べる。

試験には，HDB-11 孔から得られた深度 $424 \mathrm{~m}$ (声問層) と $672 \mathrm{~m}$ (稚内層) 付近のコアを用いた。通常, DSCA 法では含水飽和さ せない被覆した立方体の岩石供試体を作製し, 静水圧を作用させ, 直交する 3 つ面でそれぞれ $3 \sim 4$ 方向, 合計 $9 \sim 12$ 方向のひ ずみを計測し，き裂に起因するひずみテンソルを分析することで 初期地圧状態を推定する。

しかしながら, 当該岩石の物性は水分変化で変化すると考えら れたため, 原位置を模擬して含水飽和状態で試験を行うことにし た。含水飽和状態の岩石を非排水状態で圧縮すると, 間隙水圧が 上昇し適切な有効応力を得ることができないので, 直径 $30 \mathrm{~mm}$, 長さ $60 \mathrm{~mm}$ の円柱型供試体を用い排水状態で試験を行うことに した。

9 本のひずみゲージの配置と試験装置を Fig. 8 に示す。各ひず みゲージ方向の $x, y, z$ 軸に対する方向余弦を $l, m, n$ とすれば, あるひずみゲージ方向の直応力 $\sigma_{S}$ と三次元応力成分 $\sigma$ の関係は 以下のようになる。

$$
\sigma_{S}=l^{2} \sigma_{x}+m^{2} \sigma_{y}+n^{2} \sigma_{z}+2 l m \tau_{x y}+2 m n \tau_{y z}+2 n l \tau_{z x} .
$$

9 つのひずみゲージ方向についてまとめると

$$
\sigma_{S}=\mathrm{A} \sigma
$$

ここで, A は 9 行 6 列の行列,

$$
\begin{aligned}
& \sigma_{S}=\left\{\begin{array}{lllllllll}
\sigma_{a 1} & \sigma_{b 1} & \sigma_{c 1} & \sigma_{a 2} & \sigma_{b 2} & \sigma_{c 2} & \sigma_{a 3} & \sigma_{b 3} & \sigma_{c 3}
\end{array}\right\}^{\mathrm{T}} . \\
& \sigma=\left\{\begin{array}{llllllll}
\sigma_{x} & \sigma_{y} & \sigma_{z} & \tau_{x y} & \tau_{y z} & \tau_{z x}
\end{array}\right\}^{\mathrm{T}}
\end{aligned}
$$

である。

Table 2 に接着したひずみゲージの方向余弦を示す。これによ ると，ひずみゲージは独立な 6 方向以上の 7 方向に接着されてい るので三次元応力を求めることができる。重みなし最小二乗法を 用いれば三次元応力は以下のように表すことができる。

$$
\sigma=\left(\mathrm{A}^{\mathrm{T}} \mathrm{A}\right)^{-1} \mathrm{~A}^{\mathrm{T}} \sigma_{S}
$$

供試体側面の曲率を考慮し, 有効長 $2 \mathrm{~mm}$ の短いひずみゲージ を貼り付けた。ひずみゲージを水平に貼付すると最も曲率が大き くなるがその場合でも中心角は約 4 であり，ひずみゲージが曲 率を持つことによる誤差は小さい。なお，供試体の方位は HDB-11 孔で実施した BHTV 検層結果で得られた割れ目の走向傾
Table 2 Direction cosine of strain gage.

\begin{tabular}{c|c|c|c}
\hline Strain gage & $l$ & $m$ & $n$ \\
\hline $\mathrm{a} 1$ & 0 & 0 & 1 \\
\hline $\mathrm{b} 1$ & 0.612 & 0.353 & 0.707 \\
\hline $\mathrm{c} 1$ & -0.612 & -0.353 & 0.707 \\
\hline $\mathrm{a} 2$ & 0 & 0 & 1 \\
\hline $\mathrm{b} 2$ & 0 & -0.707 & 0.707 \\
\hline $\mathrm{c} 2$ & 0 & 0.707 & 0.707 \\
\hline $\mathrm{a} 3$ & 0 & 0 & 1 \\
\hline $\mathrm{b} 3$ & -0.612 & 0.354 & 0.707 \\
\hline $\mathrm{c} 3$ & 0.612 & -0.354 & 0.707
\end{tabular}

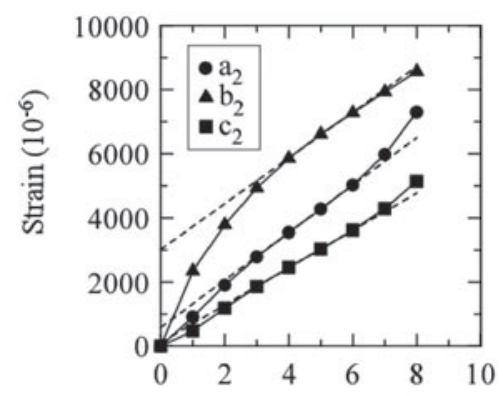

Hydrostatic pressure (MPa)

Fig.9 Example of hydrostatic pressure-strain curve obtained for the specimen at GL-424 $\mathrm{m}$.

斜方向に基づき同定した。ひずみゲージを貼付した供試体をポー ラスメタルを介して排水用の小孔を有するエンドピースに取り付 け，熱収縮チューブで被覆し，超小型三軸ベッセルに挿入し，そ の後封圧を $1 \mathrm{MPa}$ づつ上げ， 5 分後のひずみを記録することを繰 り返した。

Fig. 9 に封圧 - ひずみ線図の一例を示す。低い封圧下では，非 線形な挙動を示し, 封圧の上昇とともに線形的にひずみが増加す る。その後, 再び非線形的にひずみが増加している場合があるが, これは空隙破壊によるものと考えている 18)。線形挙動を示寸領 域で直線近似し, $y$ 切片を求めた。各方向の $y$ 切片から三次元ひ ずみテンソルを求め, 鉛直方向の直ひずみ成分で除すことで正規 化し，これに有効土被り圧を乗じて応力テンソルに変換し有効初 期地圧と見なした。得られた初期地圧 (全応力)の下半球投影図, 水平面内主応力值と方位を Fig. 10 に示す。深度 $424 \mathrm{~m}$ から取得 したコアの試験結果では最大主応力の值とその方向は, 近傍で実 施した水圧破砕試験結果と比較的類似した結果が得られた。その 他については一定の傾向が見て取れないが, 主応力軸はボーリン グ孔軸に対して一致せず若干の傾きを示している。水平面内主応 力は概ね東西方向であり, 主応力值などと比較すると概ねばらつ きは少ない。

\section{5. 水圧破砕法}

水圧破砕法は，ボーリング孔内の計測対象エリアにパッカーを 挿入し，二つのパッカーで閉塞された区間内で流体の圧入量をコ ントロールして水圧を作用させ，岩盤の破砕等を行い，得られた 諸計測值から初期地圧を算出する方法である。本方法において造 成したき裂を再開口させるときのパッカーで閉塞された区間の圧 


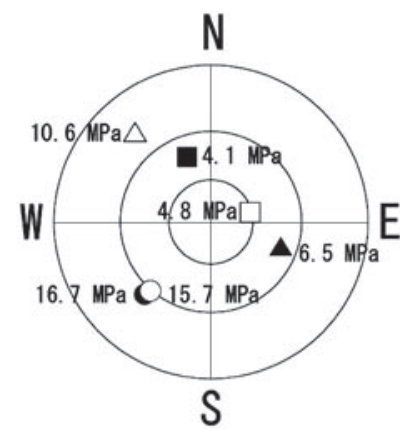

(a) GL-424 $\mathrm{m}$

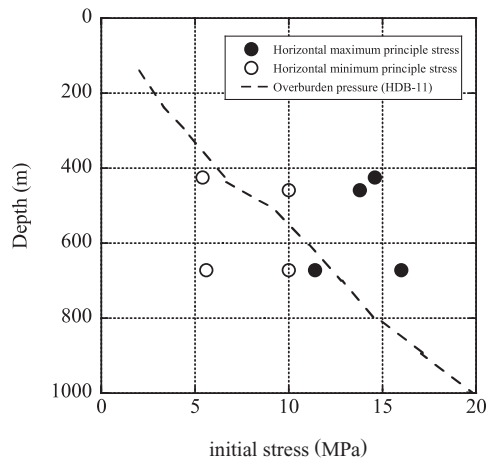

(c) Depth distribution of initial stress

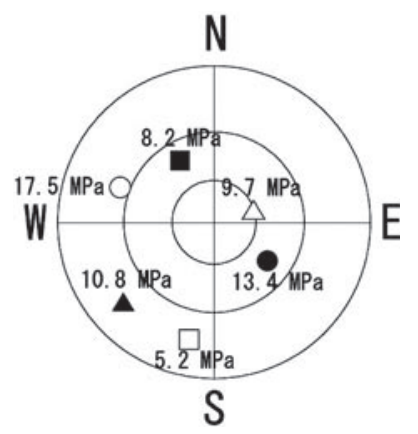

(b) GL-672 m

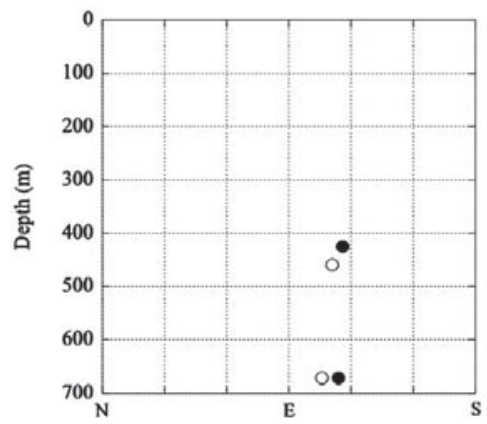

Direction of horizontal maximum principal stress $\left({ }^{\circ}\right)$

(d) Direction of maximum horizontal principal stress

Fig.10 Results of DSCA test.

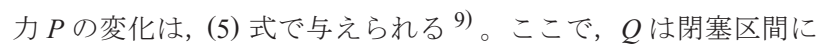
流入される流量, $\mathrm{d} V_{\mathrm{c}}$ はき裂が開口寸る際の流体体積の変化, $C$ は流量計や加圧区間までの配管を含む加圧システムのコンプライ アンスを示す。

$$
\frac{\mathrm{d} P}{\mathrm{~d} t}=\frac{Q}{\frac{\mathrm{d} V_{\mathrm{c}}}{\mathrm{d} P}+C}
$$

この式から，加圧区間内の圧力には加圧システムのコンプライ アンスの值が大きく影響している。水圧破砕試験では掘削用の ロッドを加圧配管として使用寸るが，その場合，加圧システムの コンプライアンスが大きくなることから，き裂開口圧を精度良く 検出することが難しくなる。そのため, 本研究は同和工営社製の コンプライアンスの小さいワイヤラインタイプの水圧破砕システ ムを採用することにした。本システムは樹脂製高圧ホース，ワイ ヤラインおよびストラドルパッカー ( 同和工営社製, 耐圧 20 $\mathrm{MPa})$ から構成されている。ストラドルパッカーには，パッカー エレメントへの加圧から加圧区間への加圧へと流路を切り替える ためのプッシュプルバルブ，孔内水圧，圧入流量を測定するため の圧力変換機 (共和電業社製, PGM-500KD, 測定範囲 49.03 $\mathrm{MPa}$ )，小型流量計 (Japan Flow Control Co., MF30，測定範囲 500 $\mathrm{cc} / \mathrm{min})$ を設置し，地表には，孔内水圧と圧入流量を記録するた めのパーソナルコンピュータを配置した。

孔壁が安定した箇所を試験区間に選定するため, ボーリングコ アの鑑定, RQD, キャリパーおよび $\mathrm{EMI}$ 検層の結果を参考にし, HDB-1 孔の深度 $381 \mathrm{~m}$ (声問層), $585 \mathrm{~m}$ (稚内層), HDB-2 孔の 深度 $282 \mathrm{~m}$ (稚内層)，536 m (稚内層) を試験区間とし実施した。 試験中，パッカーエレメントの破裂・抑留やバルブが作動しにく くなる現象が頻発した。この原因は, 孔内水として泥水を使用し
たことや時間経過に伴い孔壁付近の変状が大きくなったことや抑 留時のパッカーエレメントの回収に伴う引張力が不足したことな どが原因として考えられる。孔壁の変状の大きい堆積軟岩の場合, このシステムのような孔壁とのクリアランスが小さい装置を使用 すると, 装置の抑留が今後も起こる可能性が十分考えられた。検 層や初期地圧測定後のボーリング孔には地下研究施設の建設に伴 う周辺一の水理環境に与える影響を確認するためのモニタリング 装置を設置することから，HDB-1, 2 孔以降の初期地圧の計測で は, HDB-1, 2 孔で使用したワイヤラインタイプの水圧破砕シス テムの採用は断念し, 通常のロッドタイプの水圧破砕システムを 採用することとした。

Fig. 11 に水圧破砕前の孔壁のインプレッションパッカーによ る型取りの結果を示す。この孔壁の損傷は加圧に伴う損傷ではな くボーリングの掘削に伴う応力集中による破壊, すなわちボア ホールブレイクアウトであると考えた。そこで, ボアホールブレ イクアウトの情報を使用した初期地圧の算出を試みた。

ブレイクアウトを利用した解析に必要なブレイクアウトの挟み 角幅はインプレッションパッカーの型取りより, 深度方向 $1 \mathrm{~cm}$ 毎のボアホールブレイクアウトの挟み角の平均值を算出した。主 応力の一つがボーリング孔軸に平行であると仮定すると, 水平面 内最大主応力 $S_{\mathrm{H}}$ は岩石の一軸圧縮強さ $C$, ブレイクアウトの挟 み角 $2 \phi_{\mathrm{b}}$, 水平面内最小主応力 $S_{\mathrm{h}}$, 間隙水圧 $P_{0}$ を用い, (6) 式で 表現される ${ }^{19) 。}$

$S_{\mathrm{H}}=b_{\mathrm{W}}-S_{\mathrm{h}} m_{\mathrm{W}}$

ここで， $b_{\mathrm{W}}, m_{\mathrm{W}}$ は (7) 式ならびに (8) 式で表される。

$b_{\mathrm{W}}=\frac{C+2 P_{0}}{1-2 \cos \left(\pi-2 \phi_{\mathrm{b}}\right)}$ 


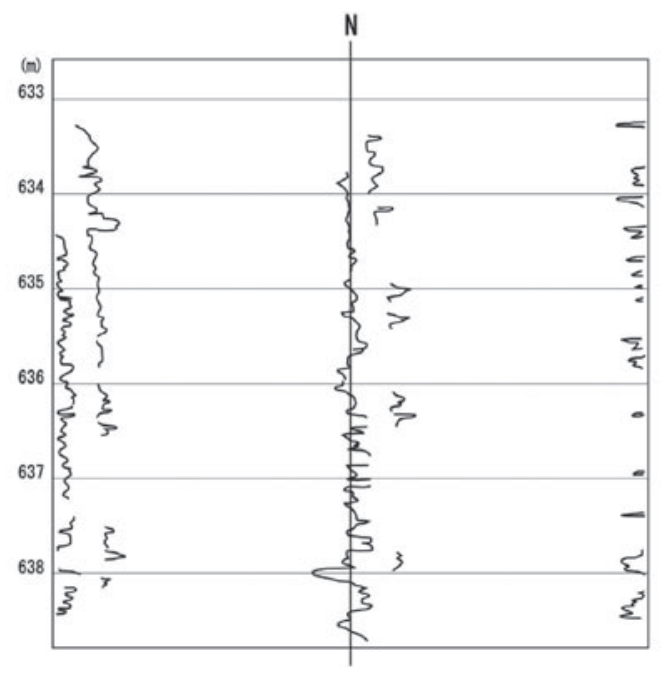

Fig.11 Example of borehole wall impression (HDB-1).

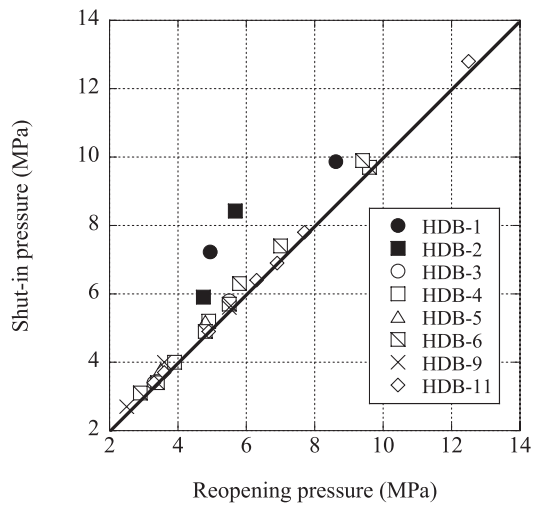

Fig.12 Relationship between shut-in and reopening pressure.

$m_{\mathrm{W}}=\frac{1+2 \cos \left(\pi-2 \phi_{\mathrm{b}}\right)}{1-2 \cos \left(\pi-2 \phi_{\mathrm{b}}\right)}$

岩石の一軸圧縮強さ $C$ は, ブレイクアウトが生じた領域の岩 石コアを使用し, 水平面内最小主応力 $S_{\mathrm{h}}$ については, その領域 で計測を行っていないため, 付近で実施した水圧破砕試験で得ら れた最小主応力を線形補完した。 $P_{0}$ については, ボーリング孔 を利用した間隙水圧計測により, 当地域に分布する岩盤内の間隙 水圧は地表からの水頭にほぼ等しいと予想されるため, 深度相当 の水頭を間隙水圧として与え解析を行った。

Fig. 12 にき裂開口圧とき裂閉口圧の関係を示す。ロッドタイ プの水圧破砕システムの計測データ (HDB-3, 4, 5, 6, 9, 11) は, き 裂開口圧がき裂閉口圧の值と非常に近い。このことは，(5) 式で 示したようにロッドタイプの水圧破砕システムは, 掘削ロッドを 流体を圧入する導管に使用しているため, コンプライアンスがワ イヤラインタイプのシステムと比べ大きく, 圧力一時間曲線が線 形から非線形に変わる応力, 寸なわちき裂開口圧を精度良く読み 取れなかったと考えられる。そのため, 本論文の水圧破砕試験結 果では HDB-1, 2 孔以外で得られた水圧破砕の応力值は, 除外し て記載することにする。ただし, 最大主応力の方位については, 方位の測定結果が水圧破砕システムのコンプライアンスに依存し ないと考えられるため, HDB-1, 2 孔以外の測定結果も記載して いる。

水圧破砕試験結果を Fig. 13 に示す。(a) は, 深度と水平面内最

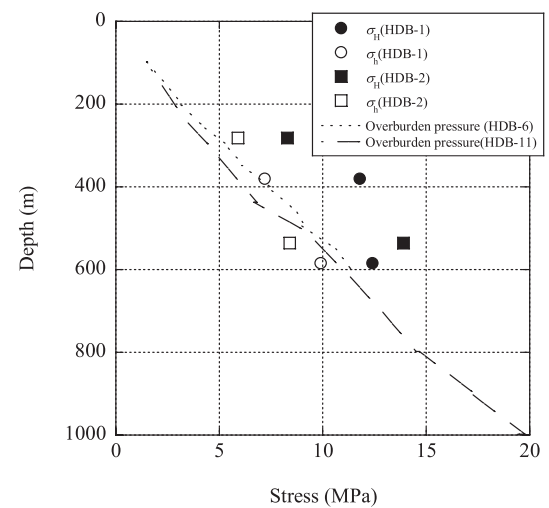

(a) Relationship between initial stress and depth.

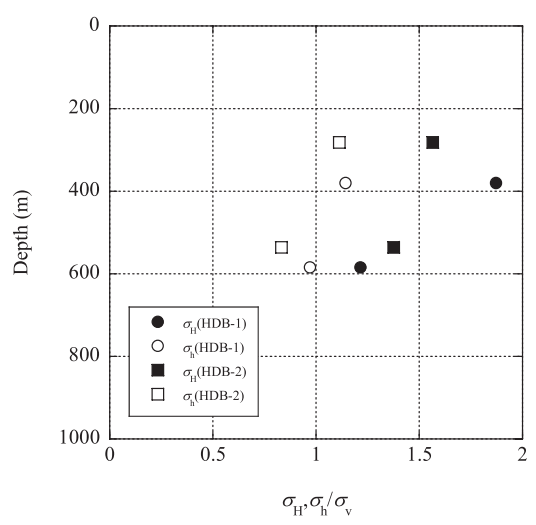

(b) Ratio of principal stress

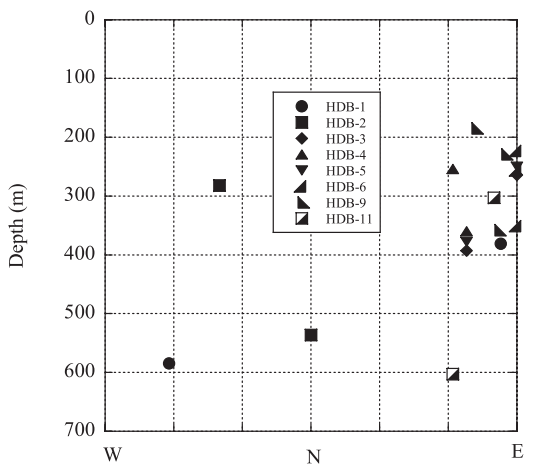

(c) Direction of maximum horizontal principal stress.

Fig.13 Results of hydraulic fracturing.

大・最小主応力と密度検層結果から算出した土被り圧との関係を, (b) は, 深度と鉛直土被り圧に対する水平面内最大・最小主応力 の比との関係を，(c) は，最大主応力の方位を示している。(a)よ り, 最大主応力, 最小主応力ともに深度が増加するにつれて線形 的に応力值が増大寸る。そして, (b) よりデータ数は少ないが深 部では最大主応力值が減少し, 比較的等方的な応力状態に近づく。 また (c) より主応力方向については研究所設置地区内においては 全てのデータがほぼ東西方向に卓越している。ただし, 研究所設 置地区から約 $6 \mathrm{~km}$ 南方にある HDB-2 孔については研究所設置地 区の応力状態と異なり主応力が南北方向に卓越していることがわ かる。

ボアホールブレイクアウトの情報から算出した結果を Fig. 14 (a)〜 (c) に示す。最小主応力值については水圧破砕データを外挿 して用いた。(a)，(b)より最大主応力值については水圧破砕試験 


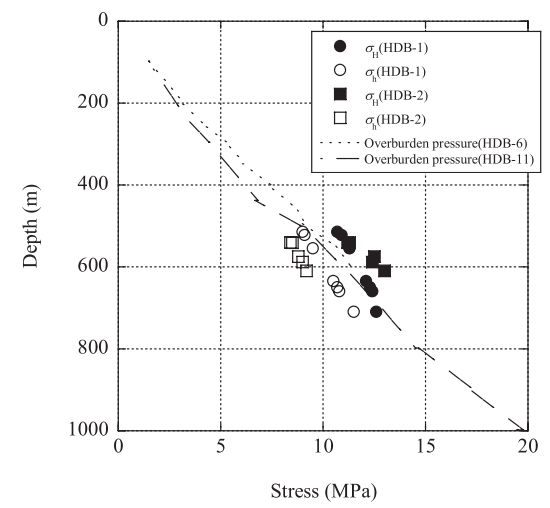

(a) Relationship between initial stress and depth

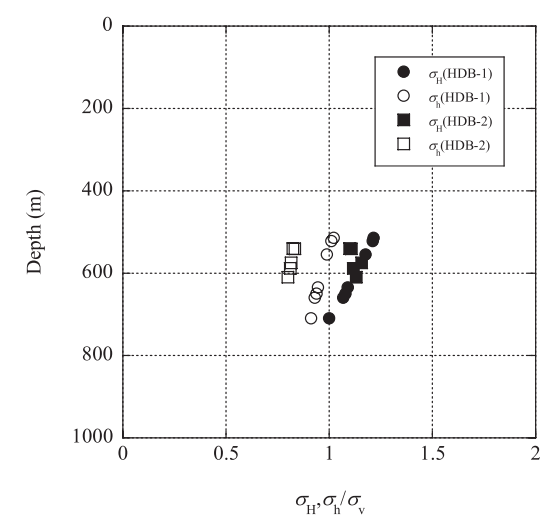

(b) Ratio of principal stress

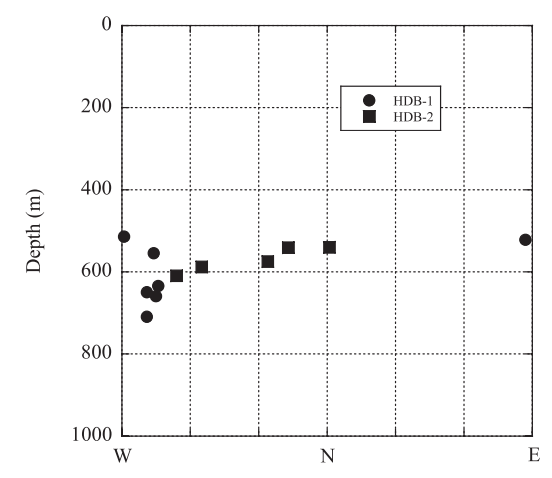

(c) Direction of maximum horizontal principal stress

Fig.14 Results of borehole breakout method.

と比較してやや小さいが，それ以外では水圧破砕試験結果と類似 している。(c)より主応力方向については, 研究所設置地区内の 結果ではほぼ東西方向に卓越し, 研究所設置地区外の HDB-2 孔 では南北方向に卓越しており，水圧破砕試験結果と似た傾向を示 す。上記の結果から，ボアホールブレイクアウトから算出した初 期地圧は, 水圧破砕試験より若干小さな值が示されたものの，応 力值・方向ともに補助的に適用可能な手法と思われる。

水圧破砕試験ならびにボアホールブレイクアウトの情報から算 出した応力結果より, 深度によってその程度は異なるが, 当該地 域の初期応力は, 若干の偏圧状態にあり, その程度は土被り圧と 最大主応力との比がおよそ 2 倍までの範囲内にあるといえる。

\section{6. 考察}

幌延地域に分布する新第三紀堆積岩に対する AE 法, DSCA 法,
水圧破砕法の適用性について整理し, これらの方法で得られた結 果に基づいて研究所設置地区内の応力状態について考察するとと ともに, 計測エリア内に作用する造構作用や深層ボーリング調查 で実施したBHTV 結果との対比から，推定された初期応力状態 の妥当性について検討する。

$6 \cdot 1$ 幌延地域に分布する珪質岩への AE 法, DSCA 法, 水 圧破砕法の適用性

ここでは，先に示した結果から推定される新第三紀堆積岩に対 する $\mathrm{AE}$ 法, DSCA 法，水圧破砕法の適用性について述べる。 $\mathrm{AE}$ 法については, 既往の研究で, 応力解放から試験までの経過時間 や, 高い応力レベル下での岩石の内部構造の損傷で, カイザー効 果が不明瞭になることが指摘されている。本論文で示したように 一軸圧縮強さの $40 \%$ 程度の先行応力を載荷させ, その後経過時 間を置かず速やかに軸圧を加えた場合には, 先行応力付近で $\mathrm{AE}$ 発生数は増大した。しかし, 載荷後の経過時間が 1 時間ほどの状 態で先行応力付近の $\mathrm{AE}$ 発生数の増分が不明瞭になったように, 当該地域の珪質岩に対しては, $\mathrm{AE}$ の発生挙動にコア採取からの 経過時間が大きく影響すると考えられる。したがって, 当該地域 の珪質岩に対して $\mathrm{AE}$ 法を適用する場合, コア採取後速やかに試 験を行う必要があるが, コアの採取, コア観察, 試験機関までの 運送, 試験準備などの実務上の制約条件が加わることを考えると, 原位置岩盤の初期地圧の定量的な評価には, 相当に工夫した試験 フローが必要である。そして, 今回の研究では十分な検討を行う ことができなかったが，今後検討す心゙き事項としては，供試体軸 方向の直応力以外の応力成分の影響, ボーリング時の応力集中の 影響, 応力解放による緩みの影響, コア採取による温度变化によ る影響等が挙げられる。

一般的にコア法の場合, 岩石内部に記憶されている応力履歴に 対するコア採取からの経過時間の影響が大きいが, DSCA 法の場 合は経過時間の影響をそれほど受けないといわれている(ただ し, 物理的・化学的な風化を考慮すると早期に実施することが望 ましい） ${ }^{20)}$ 。大深度を対象とした通常の水圧破砕試験の場合, 主応力軸は鉛直土被り圧に等しいと仮定され，ボーリング孔軸に 対して水平面方向の主応力状態しか算出することができないが, DSCA 法では，1つのコアを用いて三次元的な応力状態を算出で きる。DSCA 法を当該珪質岩に対して適用したところ, 試験点数 は少ないが少なくとも比較的硬質な稚内層の岩石においては, 水 平面内の最大主応力の方向はほぼ東西方向を向いており, 原位置 計測結果とほぼ整合的であった。しかし，応力比については水圧 破砕法やボアホールブレイクアウトの観測結果から求めた応力值 と比較して大きい。地下深部の初期地圧の一般的な傾向について 既往の検討結果 ${ }^{1)}$ によると, 平均水平地圧 $\sigma_{\mathrm{Hav}}$, 鉛直方向の直応 力 $\sigma_{\mathrm{Z}}$, 測定深度 $h$ との関係は,

$$
\frac{\sigma_{\mathrm{Hav}}}{\sigma_{\mathrm{Z}}}=\frac{155}{h}+0.65
$$

で近似されている。高レベル放射性廃棄物の地層処分事業におけ る法令上定められた深度 $300 \mathrm{~m}$ を(9) 式に代入すると, おおよそ 1.2 を示す。原位置に作用している造構作用や地山の不均質性を 加味すると, 地下深部に作用している応力状態を定式化する上で 多少のバラツキはあるとは考えられるが，今回実施したDSCA 法の応力比と地下深部に作用している初期応力の一般的な傾向と は差がある。これらの要因として, コア採取による応力解放と内 在する弱面の方向性や密度, 間隙水圧の変化などが考えられるが, これらの関係についての基礎的な検討は十分であるとはいえな 


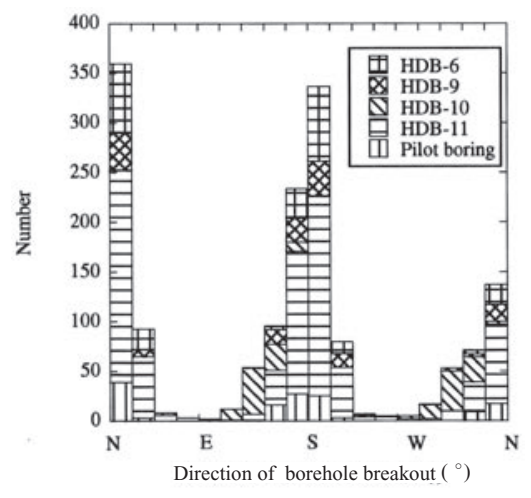

(a) Direction of borehole breakout
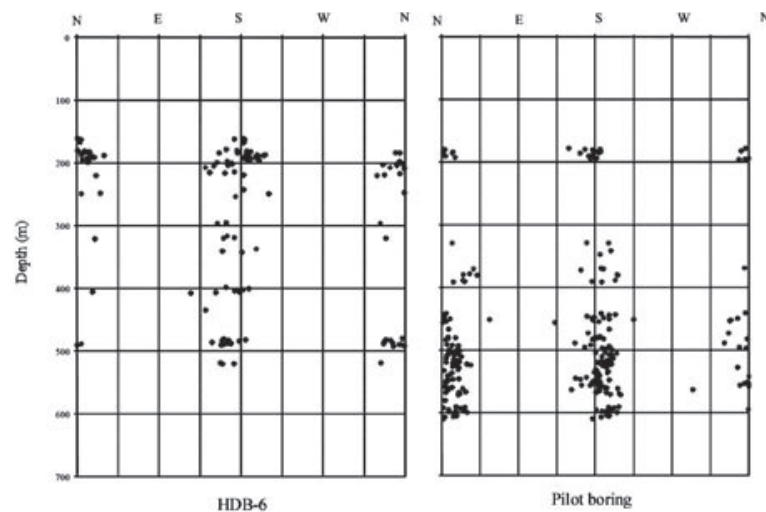

(b) Relationship between depth and direction of borehole breakout

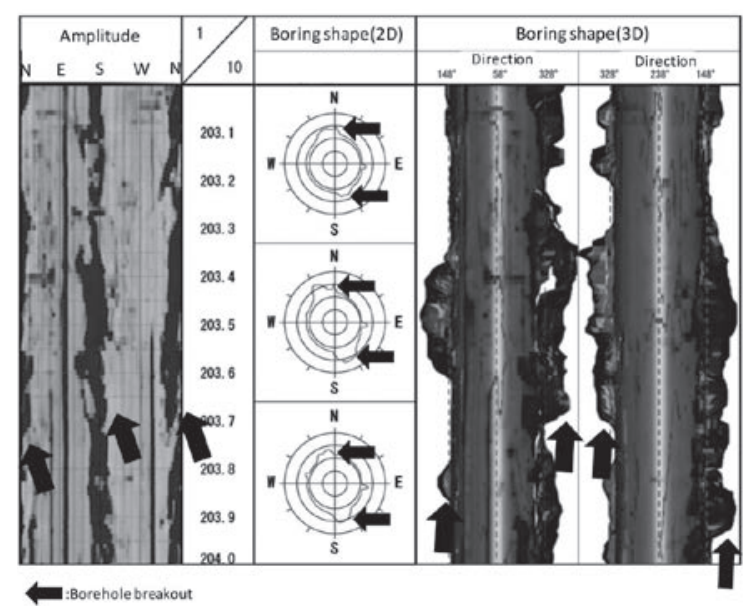

(c) Boring shape estimated from BHTV logging (Pilot boring)

Fig.15 Result of borehole breakout taken from BHTV logging.

い。したがって，これらの検討やその他の各種コア法に関する検 討は, 今後原子力機構が実施する坑道内での調查においても継続 すべき課題と考えている。

水圧破砕法については, 加圧システムのコンプライアンスの小 さいワイヤラインタイプの水圧破砕システムと掘削配管を加圧配 管として使用したロッドタイプの二つのタイプの水圧破砕システ ムを使用し，作業性や適用性の検討を実施した。作業性について は, 本研究の対象岩盤が軟弱な新第三紀の堆積岩であり孔壁の変 状が大きいこと, ボーリング孔内には清水と比較し粘性の大きい 泥水が充填されていること, ワイヤラインタイプの水圧破砕シス テムは高い精度で計測を行うため孔壁とのクリアランスが小さい

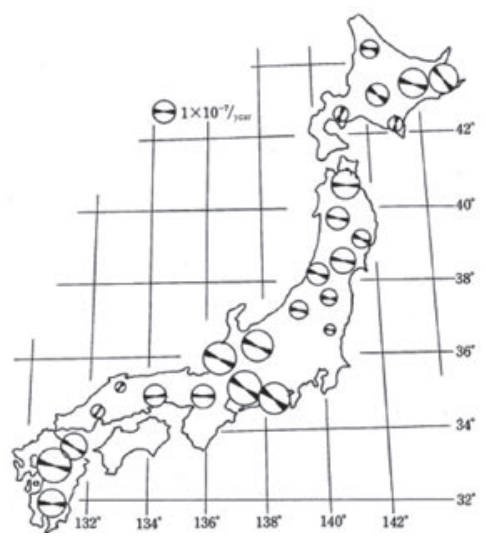

Fig.16 Strain in Japan obtained from triangular surveying ${ }^{21)}$.

ことなどから，ワイヤラインタイプの水圧破砕システムについて はパッカーエレメントの破裂・抑留やバルブが作動しにくくなる 現象が頻発し，ロッドタイプの計測システムと比較して高度な作 業が要求される結果となった。一方, 適用性については, ロッド タイプのシステムの場合, パッカーならびに配管系のコンプライ アンスが大きくなるため，き裂開口圧を精度良く読みとることが 困難であった。そのため, 測定精度という点では, ワイヤライン タイプの水圧破砕システムを採用すべきであるが，孔壁の変状が 大きい堆積軟岩の場合は，孔壁とのクリアランスに裕度を設けた システムを開発することが望ましいといえる。

\section{$6 \cdot 2$ 幌延地域の応力状態と造構作用との関係}

水圧破砕法ならびにブレイクアウト法から算出された初期地圧 測定結果によると, 主応力值は深度の増大とともに線形的に増大 することがわかった。水平面主応力は, 深部では等方的な応力状 態に近づくが，いずれも偏圧状態下にある。そのため，当地域の 応力状態は地下深部に作用している土被り圧以外に造構作用など の影響を受け複雑な応力下にあるといえる。主応力方向について は，研究所設置地区内の深層ボーリング孔 (HDB-1, 3, 4, 5, 6, 9, 11)の水圧破砕試験結果によるとほぼ東西方向を示していること がわかった。一方, 北進地域に存在する研究所設置地区から約 6 $\mathrm{km}$ 南方の上幌延地域に存在する HDB-2 孔の水圧破砕試験結果に よると, 最大主応力方向がほぼ南北方向を示しており, 北進地域 の応力状態と異なっている。Fig. 15 に HDB-6, 9, 10, 11, 先行ボー リングの BHTV 調查結果から判断されたボアホールブレイクア ウトの発生方位, HDB-6 と先行ボーリングのボアホールブレイ クアウトと深度, BHTV から算出した先行ボーリングの 2 次元と 3 次元の孔壁の形状復元結果を示す。試錐孔によって発生頻度の 違いはあるものの, 深度方向に断続的に孔壁の破壊が生じており, その領域は南北方向に集中的に発生している。このことからもこ れらのボーリング孔周辺に作用している水平面内最大主応力は概 ね東西方向と推定できる。

上記に示した幌延地域で計測した初期地圧測定結果と当地域に 作用する造構作用との対応関係を検討するために, Fig. 16 に 1974 年に発表された最近 60 年間の測量結果から求めた測地学的 な水平ひずみの変化を示す21）。今回，研究対象とした北海道北 部は，大局的に $1 \times 10^{-7} /$ 年のひずみ速度で地表が圧縮を受けて おり，その方向は概ね東西方向にある。また，幌延地域の西部に 発達する褶曲構造は, 微小地震のメカニズム解, 海域の音波探査 断面および陸域の反射法地震探査断面に基づくと, 東西圧縮の造 構作用により発達したと考えられている ${ }^{22)}$ 。これらの造構作用 は, 今回実施した初期地圧測定結果と概社調和的な傾向を示して 
おり，当地域の初期地圧状態は造構作用の影響を反映し，大局的 には東西方向の偏圧環境下に晒されていると推定できる。

\section{7. 結言}

本研究では, 特に高レベル放射性廃棄物の地層処分に代表され る地下構造物の合理的な設計・施工への寄与を主たる目的とし， 北海道北部に位置する幌延町を一種のケーススタディとして取り 扱い，幌延地域に分布する新第三紀の珪質岩に対して初期地圧に 関する室内試験や原位置試験を行い，その適用性を検討した。そ して, その結果に加え深層ボーリング調査で実施した BHTV 結 果や計測エリア内に作用する造構作用から北海道幌延地域に作用 する初期応力状態について議論した。本研究で得られた主な知見 は以下のようである。

1) $\mathrm{AE}$ 法により得られた初期地圧は土被り圧より低い值を示した。 これは予備試験で得られたようにカイザー効果の時間依存性 の問題やボーリングコア採取時の応力解放により生じた微細 き裂の影響などが原因として考えられ，珪質岩に対する $\mathrm{AE}$ 法 の適用性については今後の検討課題としたい。

2) DSCA 法については, 深度 $600 \mathrm{~m}$ 台の一部の供試体を除いては 原位置試験の結果と類似した結果が得られた。また, 最大主 応力の方位については概初東西方向を示しており, データ数 は少ないものの $\mathrm{AE}$ 法と比較し原位置試験と整合的な結果と なった。

3) 水圧破砕法において, 作業性という観点からは, 掘管を圧力 配管に使用するロッドタイプの水圧破砕システムの方が， ワ イヤラインタイプの水圧破砕システムと比較し抑留等のリス クが少ないが，前者のシステムはパッカーや掘管の剛性の影 響から精度良くき裂開口圧を測定することが困難であった。

4) 水圧破砕試験結果によると, 最大主応力, 最小主応力ともに 深度の増大とともに線形的に増大していた。また，最大主応 力と土被り圧の深度分布から, 初期地圧は浅部では偏圧環境 にあるが，深部では相対的に等方的な応力状態に近づくとい える。主応力方向は，ほぼ東西方向を向いており当地域に作 用する造構作用と調和的であった。

原子力発電環境整備機構によると, 処分事業は地上からの概 要調查, 地下坑道を利用した精密調查と段階的な調查を経て進め られることになっている。幌延深地層研究計画においても, 地上 からの調查で得られた初期地圧測定結果の妥当性の確認や更新を 行うために，坑道内での初期地圧計測を継続して行うこととして
いる。今回, 新第三紀堆積岩に対して幾つかのコア法の適用性を 検討したが, 坑道内での調查においても継続して検討寸る必要が あると考えている。

謝辞本原稿は, 幌延深地層研究計画の地上からの調查研究 段階ならびに現在実施している坑道掘削時の調査研究段階で実施 された試錐調查結果の内, 特に力学調查に特化した内容を取りま とめたものである。試錐調査業務に携わって頂いた多数の所内外 の関係各位に深く感謝する。原稿の作成作業の際は, 幌延深地層 研究ユニットの中司昇ユニット長, 堆積岩工学技術開発グループ の畑中耕一郎グループリーダー，杉田裕チームリーダー，山崎雅 直氏 ( 現在, 東京電力 ) に適切な閲読をいただいた。ここに深く 感謝申し上げる。

\section{References}

1) T. Saito , T. Ishida , M. Terada and Y. Tanaka : Proc. of JSCE, 394/III-9 (1988), pp. 71-78. 2) Brown, E.T. and Hoek, E. : Int. J. Rock Mech. Min. Sci.\&Geomech. Abstr., 15 (1978), 211-215.

3) Linder, E.N. and Halpern, J.A. : Int. J. Rock Mech. Min. Sci \&Geomech. Abst. , 15 (1978), 183-203.

4) H. N. Ghimire, Y. Ishijima, T. Sugawara and S. Nakama: Journal of MMIJ , 120 (2004) , 32-38.

5) T.Kanagawa, M.Hayashi and Y.Kitahara : Denryokucyuokenkyujyo Hokoku, 377003 (1978), $1-31$.

6) H. N. Ghimire , Y. Ishijima , T. Sugawara, H. Matsui and S. Nakama: Journal of MMIJ , 120 (2004), 545-554

7) T.Sato , H.Matsui and K.Sugihara : Jour. of Nuclear Fuel Cycle and Environment, 4 (1998), 83-89.

8) K.Sakaguchi , H.Yoshida , M.Minami , M.Hara , Y.Suzuki and K.Matsuki: Journal of MMIJ , 122 (2006), 338-344.

9) T.Ito , K.Evans , K.Kawai and K.Hayashi : Int. J. of Rock Mech. and Min. science, 36 (1999) 811-826.

10) E.Ishii K.Yasue, T.Tanaka, R.Tsukuwi, K.Matsuo, K.Sugiyama and S.Matsuo: Jour. Geol. soc. Japan, 112 (2006), 301-314.

11) D.Wei, T.Seno, Flower, M., Chung, S.L., Lo, C.H. and Lee, T.Y. (Eds.): Mantle Dynamics and Plate Interactions in East Asia, Geodynamics Series 27, American Geophysical Union, Washington, D.C., USA, pp. 337-346.

12) H.Fukasawa: Jour. Geol. soc. Japan, 91 (1985), 833-849

13) S.Niunoya and H.Matsui : Proc. of the 35th Symposium on Rock mech., 35 (2006), 177-182.

14) I.Eiichi, Y.Kenichi, O.Hiroto, F.Akira, H.Takeshi and N.Mitsuhiro : Jour. Geol. soc. Japan, 6 (2008), 286-299.

15) K.Hata , K.Michihiro, H.Yoshioka and K.Sugihara: J. Soc. Mat. Sci. Japan , 44 (1995) , 885-890.

16) K. Ishibashi, K.Konagai, Y.Mitarai and Y. Matsumoto: Proc. of JSCE , 364 (1985) , pp. 23-30.

17) H.Matsui and Y.Takuya: Proc. JSCE Annual Meeting (2004), CSI-012.

18) H.Sanada , H.Matsui and Y.Fujii : Proceedings of the ISRM-Sponsored International Symposium on Rock Mechanics:"Rock Characterisation, Modelling and Engineering Design Methods" SINOROCK2009 (2009), CD-ROM.

19) Japan Nuclear Cycle Development Institute : Japan Nuclear Cycle Development Technical Report, JNC TN1400 2002-010 (2002), 7-27-7-29.

20) Y.Oikawa and T Yamaguchi: Proc.MMIJ Annual Meeting (2000), pp. 67-70.

21) Nihon-Sokuchi-Gakkai : Sokuchi-Gaku-no-Gaikan (Nihon-Sokuchi-Gakkai, Tokyo, 1974), p. 511.

22) Japan Nuclear Cycle Development Institute : Japan Nuclear Cycle Development Technical Report, JNC TN1400 2005-014(2005), 13-17. 